\title{
Neutrophils Exposed to Bacterial Lipopolysaccharide Upregulate NADPH Oxidase Assembly
}

\author{
Frank R. DeLeo, ${ }^{\star}$ Jan Renee, ${ }^{\star}$ Sally McCormick, ${ }^{\star}$ Michio Nakamura, ${ }^{\S}$ Michael Apicella, ${ }^{\ddagger}$ Jerrold P. Weiss, \\ and William M. Nauseef* \\ *Department of Medicine and the Inflammation Program, Veterans Administration Medical Center and University of Iowa, and \\ ${ }^{\ddagger}$ Department of Microbiology, University of Iowa, Iowa City, Iowa 52246; ${ }^{\circledR}$ Department of Biochemistry and the Institute of Tropical

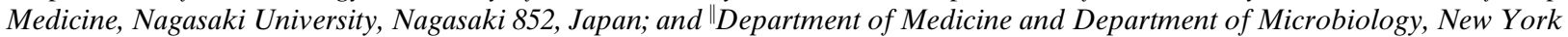 \\ University School of Medicine, New York 10016
}

\begin{abstract}
Bacterial LPS is a pluripotent agonist for PMNs. Although it does not activate the NADPH-dependent oxidase directly, LPS renders PMNs more responsive to other stimuli, a phenomenon known as "priming." Since the mechanism of LPS-dependent priming is incompletely understood, we investigated its effects on assembly and activation of the NADPH oxidase. LPS pretreatment increased superoxide $\left(\mathrm{O}_{2}^{-}\right)$generation nearly 10 -fold in response to $N$-formyl methionyl leucyl phenylalanine (fMLP). In a broken-cell $\mathrm{O}_{2}{ }^{-}$-generating system, activity was increased in plasma membrane-rich fractions and concomitantly decreased in specific granule-rich fractions from LPS-treated cells. Oxidation-reduction spectroscopy and flow cytometry indicated LPS increased plasma membrane association of flavocytochrome $b_{558}$. Immunoblots of plasma membrane vesicles from LPS-treated PMNs demonstrated translocation of p47-phox but not of p67-phox or Rac2. However, PMNs treated sequentially with LPS and fMLP showed a three- to sixfold increase (compared with either agent alone) in plasma membrane-associated p47-phox, p67-phox, and Rac2, and translocation paralleled augmented $\mathrm{O}_{2}^{-}$generation by intact PMNs. LPS treatment caused limited phosphorylation of p47-phox, and plasma membrane-enriched fractions from LPS- and/or fMLP-treated cells contained fewer acidic species of p47-phox than did those from cells treated with PMA. Taken together, these studies suggest that redistribution of NADPH oxidase components may underlie LPS priming of the respiratory burst. (J. Clin. Invest. 1998. 101:455-463.) Key words: inflammation - superoxide • endotoxin - respiratory burst $\bullet$ polymorphonuclear leukocytes
\end{abstract}

\section{Introduction}

Human polymorphonuclear leukocytes (neutrophils or PMNs) are mobilized readily to sites of infection and injury where they destroy invading microorganisms and remove damaged

Address correspondence to Dr. William M. Nauseef, Department of Medicine, University of Iowa, 200 Hawkins Drive, Iowa City, IA 52246. Phone: 319-356-1739; FAX: 319-356-4600; E-mail: william-nauseef@ uiowa.edu

Received for publication 17 June 1997 and accepted in revised form 20 November 1997.

The Journal of Clinical Investigation

Volume 101, Number 2, January 1998, 455-463

http://www.jci.org tissue and debris (1). PMNs possess a multicomponent NADPHdependent oxidase which generates superoxide $\left(\mathrm{O}_{2}^{-}\right)$(for a review see reference 2 ) and other reactive oxygen species (e.g., $\mathrm{H}_{2} \mathrm{O}_{2}, \mathrm{OH} \bullet$, and $\mathrm{HOCl}$ ) that contribute greatly to the ability of PMNs to kill invading pathogens $(3,4)$. In the absence of a functioning oxidase, as is seen in patients with chronic granulomatous disease (CGD) ${ }^{1}(5)$, individuals have increased susceptibility to life-threatening bacterial and fungal infections (6).

In resting PMNs, the inactive oxidase is unassembled, with required components segregated into plasma membrane and cytosolic locations (7-9). During activation, required cytosolic components p47-phox (10-13), p67-phox $(10,14)$, and Rac2 $(15,16)$ translocate to the plasma membrane to associate with flavocytochrome $b_{558}(7,17,18)$, the key membrane-bound component, thereby assembling the active $\mathrm{O}_{2}^{-}$-generating complex. Rap1A, a low molecular weight GTP-binding protein associated with flavocytochrome $b_{558}(19)$, and p40-phox, another cytosol-derived component (20), appear to have important but as of yet undefined roles in NADPH activation and $\mathrm{O}_{2}^{-}$-generation.

Flavocytochrome $b_{558}$ appears to contain all of the redox components necessary for the transfer of electrons from NADPH to molecular oxygen, producing $\mathrm{O}_{2}^{-}(21,22)$. In resting cells, $\sim 10 \%$ of flavocytochrome $b_{558}$ is contained within the plasma membrane, $5-15 \%$ in the secretory vesicles, and the remainder $(75-90 \%)$ stored in the membrane of specific granules $(23,24)$. Flavocytochrome $b_{558}$ is recruited to the plasma membrane from cytosolic granules after stimulation, a process which upregulates the oxidase and enables PMNs to direct production of $\mathrm{O}_{2}^{-}$to engulfed pathogens (23-25).

Lipopolysaccharide (LPS or endotoxin) elicits a variety of PMN responses, including receptor upregulation $(26,27)$, actin assembly (28), and adherence (29), and primes the cell for enhanced release of superoxide $\left(\mathrm{O}_{2}{ }^{-}\right)$in response to other stimuli such as $N$-formylated bacterial peptides $(26,30-34)$. Thus, LPS released from invading pathogens at sites of infection may, in a sense, sensitize local phagocytic cells to be more responsive and thereby amplify the inflammatory response. This amplified response may in turn rapidly eliminate the pathogens and/or result in untoward sequelae, such as manifestations of the systemic inflammatory response syndrome. However, LPS itself does not elicit significant $\mathrm{O}_{2}{ }^{-}$generation, and the molecular basis of PMN priming by LPS is unknown.

To define further the mechanisms of priming for an enhanced respiratory burst, we investigated the effects of LPS on

1. Abbreviations used in this paper: $\mathrm{CE}$, cell equivalents; $\mathrm{CGD}$; chronic granulomatous disease; DiC8, diacylglycerol; fMLP, $N$-formyl methionyl leucyl phenylalanine; NEPHGE, nonequilibrium $\mathrm{pH}$-gradient electrophoresis. 
the NADPH oxidase. Our data indicate that LPS treatment (a) upregulated plasma membrane association of flavocytochrome $\mathrm{b}_{558}$ and $(b)$ significantly enhanced assembly of the cytosolic oxidase factors with the plasma membrane-bound NADPH oxidase after stimulation with $N$-formyl methionyl leucyl phenylalanine (fMLP). The accentuated assembly of the oxidase at the plasma membrane correlated directly with the enhanced respiratory burst observed in intact cells. Our results suggest that increased plasma membrane association of NADPH oxidase components after LPS exposure is the basis for the enhanced respiratory burst observed in LPS-treated PMNs.

\section{Methods}

Materials. Endotoxin-free dextran was purchased from USB Biologicals (Cleveland, OH). GTP- $\gamma-S$ and superoxide dismutase were obtained from Boehringer Mannheim Biochemicals (Indianapolis, IN). RNase-free Percoll was purchased from Pharmacia Biotech (Piscataway, NJ) and was assayed for endotoxin content. Endotoxin-free Hypaque (50\% diatrizoate sodium injection grade, USP) was obtained from Nycomed (New York, NY). Endotoxin-free $0.9 \% \mathrm{NaCl}$ and $\mathrm{dH}_{2} \mathrm{O}$ (both injection grade, USP) were obtained from Baxter Healthcare Corp. (Deerfield, IL). All other reagents were purchased from Sigma Chemical Co. (St. Louis, MO) unless specified.

Endotoxin preparation. LPS was purified from Salmonella minnesota as described previously (35). Stock solutions were prepared in Dulbecco's PBS without calcium or magnesium (DPBS) or $\mathrm{H}_{2} \mathrm{O}$ and were sonicated $15-30 \mathrm{~min}\left(47 \mathrm{kHz}\right.$ at $\left.25^{\circ} \mathrm{C}\right)$ in a water bath sonicator (model 1200; Branson Ultrasonics Corp., Danbury, CT) before each use.

Neutrophil isolation. Heparinized, venous blood was obtained from healthy individuals (or from a patient with X-linked CGD) in accordance with a protocol approved by the Institutional Review Board for Human Subjects at the University of Iowa, and PMNs were isolated as described previously using Hypaque-Ficoll density-gradient separation after dextran sedimentation (36). Purified PMNs (>96\% of the cells in the preparation) were resuspended in DPBS (or in phosphate-free loading buffer for ${ }^{32} \mathrm{P}$ labeling) and kept on ice until use. All reagents and materials used in the preparation of PMNs (e.g., DPBS, Hypaque-Ficoll, dextran/ $\mathrm{NaCl}, \mathrm{dH}_{2} \mathrm{O}$, and saline solutions) were essentially endotoxin-free (i.e., $<10.0 \mathrm{pg} / \mathrm{ml}$ ) as determined by Limulus amebocyte lysate assay (QCL-1000; BioWhittaker, Inc., Walkersville, MD).

Neutrophil priming. PMNs $\left(2-10 \times 10^{6}\right.$ cells $\left./ \mathrm{ml}\right)$ in DPBS (or loading buffer) were mixed gently at $37^{\circ} \mathrm{C}$ for the indicated times with LPS (15 or $100 \mathrm{ng} / \mathrm{ml}$, as specified) and then centrifuged at $500 \mathrm{~g}$ for $10 \mathrm{~min}$ at $4^{\circ} \mathrm{C}$. Treated PMNs were resuspended in an appropriate assay buffer (either DPBS plus glucose [DPBS ${ }^{++} / \mathrm{g}$ ] for superoxide assays, DPBS for flow cytometry, or relaxation buffer [23] for nitrogen cavitation) at specified cell densities (see below). Untreated PMNs were incubated in a manner identical to that for the LPS-treated cells but without LPS. For fMLP-activated PMNs, cells were incubated with or without LPS, as above, and then with or without $1 \mu \mathrm{M}$ fMLP at $37^{\circ} \mathrm{C}$ for the indicated time(s). PMN treatments were terminated by placing cells immediately on ice, and all subsequent procedures were carried out at $0-4^{\circ} \mathrm{C}$.

Intact PMN superoxide assays. PMNs were adjusted to $10^{7}$ cells $/ \mathrm{ml}$ and treated with 15 or $100 \mathrm{ng} / \mathrm{ml} \mathrm{LPS} \mathrm{for} 60 \mathrm{~min}$ at $37^{\circ} \mathrm{C}$. After incubation, LPS-treated or untreated PMNs were incubated with or without $1 \mu \mathrm{M}$ fMLP at $37^{\circ} \mathrm{C}$ for an additional $10 \mathrm{~min}$, and $\mathrm{O}_{2}{ }^{-}$generation was measured by the superoxide dismutase-inhibitable reduction of ferricytochrome $\mathrm{c}$ at $550 \mathrm{~nm}$ as described previously (37).

Neutrophil fractionation. PMNs $\left(5 \times 10^{6}\right.$ cells $/ \mathrm{ml}$ in DPBS $)$ treated with or without LPS for $70 \mathrm{~min}$, or with or without LPS for $60 \mathrm{~min}$ then with or without $1 \mu \mathrm{M}$ fMLP at $37^{\circ} \mathrm{C}$ for 10 additional min, were treated with 2-4 mM diisopropyl fluorophosphate for $15 \mathrm{~min}$ on ice, and then PMN subcellular fractions (plasma membrane- and specific granule-enriched fractions and a cytosol-derived fraction) were isolated using Percoll step gradients as described by Borregaard et al. (23). Plasma membrane- or specific granule-enriched fractions were resuspended in broken-cell assay buffer (38) to $10^{9}$ cell equivalents (CE)/ml for broken-cell superoxide assays or in relaxation buffer (23) for analysis by SDS-PAGE. Cavitates used for quantitative comparison were obtained from an equal number of PMNs.

Broken-cell NADPH oxidase reconstitution assay. For brokencell assays using SDS as the activating agent, $3 \times 10^{6} \mathrm{CE}$ neutrophil cytosol and $6 \times 10^{6} \mathrm{CE}$ neutrophil membranes were combined with $100 \mu \mathrm{M}$ ferricytochrome c, $10 \mu \mathrm{M}$ FAD, $10 \mu \mathrm{M}$ GTP- $\gamma-S, 100 \mu \mathrm{M}$ SDS, and buffer (38) to $600 \mu \mathrm{l}$ final volume. After a 3-min incubation with SDS, NADPH was added to a final concentration of $200 \mu \mathrm{M}$, and superoxide dismutase-inhibitable $\mathrm{O}_{2}{ }^{-}$production was monitored continuously at $550 \mathrm{~nm}$ on a single beam spectrophotometer (model DU 640; Beckman Instruments, Inc., Fullerton, CA) using an Auto 6 sampler (Beckman Instruments, Inc.) for 8-10 min. The concentrations of cytosol and membrane fractions used in these assays were adjusted so that $\mathrm{O}_{2}{ }^{-}$generation was not saturating. All samples used for comparison were analyzed simultaneously using the Auto 6 sampler.

Broken-cell assays activated with phosphatidic acid (PA) and diacylglycerol (DiC8) were done essentially as described by McPhail and colleagues (39). The contents of the PA and DiC8 assays were identical to the SDS assays except that $40 \mu \mathrm{g}$ PA and $10 \mu \mathrm{g}$ DiC8 replaced SDS, and each assay was incubated at room temperature for $30 \mathrm{~min}$ before addition of NADPH.

Spectral analysis of flavocytochrome $b_{558}$. Plasma membrane- and specific granule-enriched fractions were isolated from untreated and LPS-treated PMNs as described above. The $\gamma$-peak at $427 \mathrm{~nm}$ in oxidized minus dithionite-reduced difference spectra was used to calculate the amount of flavocytochrome $b_{558}$ in the plasma membrane- or specific granule-enriched fractions as described previously using an extinction coefficient of $106 \mathrm{mM}^{-1} \mathrm{~cm}^{-1}$ (40). The recovery of flavocytochrome $b_{558}$ from the gradients was $72.2-91.6 \%$ as determined by spectroscopy and $87.2-101.7 \%$ by SDS-PAGE and subsequent densitometry.

Flow-cytometric analysis of plasma membrane-associated flavocytochrome $b_{558}$. Plasma membrane association of flavocytochrome $b_{558}$ was determined using an mAb (7D5) which recognizes an extracellular epitope of flavocytochrome $b_{558}(41,42)$. PMNs $\left(2 \times 10^{6} \mathrm{cells} / \mathrm{ml}\right.$ in DPBS $)$ treated with or without LPS $(100 \mathrm{ng} / \mathrm{ml}$ for $5,10,20,40,60$, and $90 \mathrm{~min}$ at $\left.37^{\circ} \mathrm{C}\right)$ and with or without fMLP $(1 \mu \mathrm{M}$ added to identical untreated and LPS-treated PMNs after incubation for $60 \mathrm{~min}$ and further incubated for $1,2,5,10$, and $30 \mathrm{~min}$ at $37^{\circ} \mathrm{C}$ ) were resuspended in $\mathrm{FACS}^{\circledR}$ buffer (DPBS/2\% normal goat serum) to a final concentration of $10^{7}$ cells $/ \mathrm{ml}$. Plasma membrane association of flavocytochrome $\mathrm{b}_{558}$ was detected using 7D5 and a fluorescein-conjugated goat anti-mouse IgG antibody (Organon Teknika Corp., Durham, NC) by the method of Jones et al. (43). After staining, samples were analyzed on a FACScan ${ }^{\circledR}$ flow cytometer (Becton Dickinson, San Jose, CA) at the University of Iowa Core Flow Cytometry facility. Unfixed PMNs were used for all flow-cytometric analyses, and a single live gate was used to eliminate debris and any contaminating cells.

Translocation of NADPH oxidase components and immunoblotting. Plasma membrane-enriched fractions were prepared as described above using the method of Borregaard (23). 1-2 $\times 10^{7} \mathrm{CE}$ plasma membrane vesicles obtained from PMNs treated with or without LPS (100 ng LPS/ml for 5, 10, 20, 40, 60, or $70 \mathrm{~min}$ as indicated at $\left.37^{\circ} \mathrm{C}\right)$ and/or with or without fMLP $(1 \mu \mathrm{M}$ for an additional $10 \mathrm{~min}$ at $37^{\circ} \mathrm{C}$ ) were separated using $10 \%$ SDS-PAGE and then transferred to nitrocellulose as described previously (see p. 10.2.1 in reference 44). Immunoblots were processed using polyclonal antibody to p47-phox, p67-phox, and Rac2 (Santa Cruz Biotechnology, Inc., Santa Cruz, CA) followed by detection using enhanced chemiluminescence (Super Signal substrate; Pierce Chemical Co., Rockford, IL). Plasma membrane association of proteins was quantitated using a scanning laser densitometer (model CS-9000U; Shimadzu Corp., Kyoto, Japan). 
Phosphorylation and immunoprecipitation of p47-phox. $1.2 \times 10^{8}$ PMNs were resuspended in $1 \mathrm{ml}$ loading buffer (10 mM Na-Hepes, $138 \mathrm{mM} \mathrm{NaCl}, 2.7 \mathrm{mM} \mathrm{KCl}$, and $7.5 \mathrm{mM}$ D-glucose, $\mathrm{pH}$ 7.5, prepared with endotoxin- and RNase-free reagents: contaminating LPS was removed by filtration through a 1-ml Detoxi-Gel column [Pierce Chemical Co., Rockford, IL]) with $0.5 \mathrm{mCi} / \mathrm{ml}\left[{ }^{32} \mathrm{P}\right]$ orthophosphate and incubated at room temperature for $60 \mathrm{~min}$. After loading, $2 \times 10^{7}$ PMNs were treated with or without LPS $(100 \mathrm{ng} / \mathrm{ml}$ for $60 \mathrm{~min}$ at $\left.37^{\circ} \mathrm{C}\right)$ and then with or without fMLP $\left(1 \mu \mathrm{M}\right.$ for $10 \mathrm{~min}$ at $\left.37^{\circ} \mathrm{C}\right)$ and iced immediately. After diisopropyl fluorophosphate treatment as above, cells were resuspended in $100 \mu \mathrm{l}$ lysis buffer ( $1 \%$ Triton X-100, $0.5 \mathrm{mg} / \mathrm{ml}$ leupeptin and pepstatin A, $1 \mathrm{mM}$ PMSF, $1 \mathrm{mM}$ sodium orthovanadate, and $0.5 \%$ cetyl trimethyl ammonium bromide in Trisbuffered saline, $\mathrm{pH}$ 7.5) for $20 \mathrm{~min}$ on ice. Insoluble material was removed by centrifugation $(14,000 \mathrm{~g}$ for $30 \mathrm{~s}$ at room temperature), and the supernatants were diluted to $1 \mathrm{ml}$ with $50 \mathrm{mM}$ Tris- $\mathrm{HCl}, 190 \mathrm{mM}$ $\mathrm{NaCl}$ containing $2.5 \%$ Triton $\mathrm{X}-100$, and $1 \mathrm{mM}$ sodium orthovanadate. P47-phox was immunoprecipitated using polyclonal antibody to p47-phox and Staphylococcus protein A (Pansorbin cells; Calbiochem Corp., La Jolla, CA) using a previously described method (45). Staphylococcus protein A-immune complexes were boiled in SDS-sample buffer without reducing agent and resolved with $10 \%$ SDS-PAGE. Dried gels were subjected to autoradiography using XAR films (Eastman Kodak Co., Rochester, NY), and the [ $\left.{ }^{32} \mathrm{P}\right]$ orthophosphate incorporated into p47-phox was quantitated using a PhosphorImager (Molecular Dynamics, Sunnyvale, CA).

Since the amount of p47-phox immunoprecipitated from cells treated with or without LPS and/or fMLP and PMA was compared, we verified that the rabbit antiserum against p47-phox immunoprecipitated both native and phosphorylated p47-phox with equal efficiency (data not shown). Briefly, $10^{7} \mathrm{PMNs}$ were warmed to $37^{\circ} \mathrm{C}$ and stimulated with buffer alone (control) or $2 \mu \mathrm{g} / \mathrm{ml}$ PMA for $10 \mathrm{~min}$. Cells were lysed and processed as described above for immunoprecipitation. Immunoprecipitates were resolved by $10 \%$ SDS-PAGE, and the amount of p47-phox was quantitated. The same amount of p47-phox was recovered from control or PMA-stimulated cells.

Analysis of p47-phox phosphorylation by nonequilibrium $\mathrm{pH}$-gradient electrophoresis (NEPHGE) and SDS-PAGE was performed as described previously (46). Briefly, PMNs treated with or without LPS $\left(100 \mathrm{ng} / \mathrm{ml}\right.$ for $60 \mathrm{~min}$ at $\left.37^{\circ} \mathrm{C}\right)$ and then with or without fMLP $(1 \mu \mathrm{M}$ for $10 \mathrm{~min}$ at $37^{\circ} \mathrm{C}$ ) were disrupted by sonication, and the plasma membrane-enriched fraction was isolated as described previously (8). After $\mathrm{pH}$ resolution by NEPHGE, gels were subjected to SDSPAGE and transferred to nitrocellulose. Immunoblots were processed using polyclonal antibody to p47-phox and developed using enhanced chemiluminescence (Super Signal substrate).

\section{Results and Discussion}

Priming of intact PMNs by LPS. To determine the effect of LPS on $\mathrm{PMN} \mathrm{O}_{2}^{-}$generation, cells were incubated for $60 \mathrm{~min}$ at $37^{\circ} \mathrm{C}$ with or without LPS, and then subsequently stimulated with $1 \mu \mathrm{M}$ fMLP for an additional $10 \mathrm{~min}$ (Fig. 1). PMNs treated with LPS alone generated very little $\mathrm{O}_{2}^{-}(2.5 \pm 0.4$ nmole $\mathrm{O}_{2}^{-} / 10^{6}$ PMNs vs. $1.4 \pm 0.9$ for resting cells) (Fig. 1 , bar 2 vs. bar 1). However, PMNs treated with LPS produced nearly 10-fold more $\mathrm{O}_{2}{ }^{-}$when stimulated subsequently with fMLP $\left(24 \pm 1.8\right.$ nmole $\left.\mathrm{O}_{2}^{-} / 10^{6} \mathrm{PMNs}\right)$ than cells not treated with LPS before fMLP exposure (3.3 \pm 0.3 ) (Fig. 1, bar 4 vs. bar 3). Optimal priming effects in the absence of serum, as a source of LPS-binding protein (47), required pretreatment of PMNs with $100 \mathrm{ng} \mathrm{LPS} / \mathrm{ml}$ for $\sim 60 \mathrm{~min}$ as reported previously (30, 34 ), or as little as $1 \mathrm{ng} \mathrm{LPS} / \mathrm{ml}$ in the presence of $100 \mathrm{ng} \mathrm{LBP} /$ $\mathrm{ml}$ (data not shown). Pretreating PMNs with LPS increased greatly the amplitude of the respiratory burst induced by fMLP but did not alter the duration of NADPH oxidase activ-

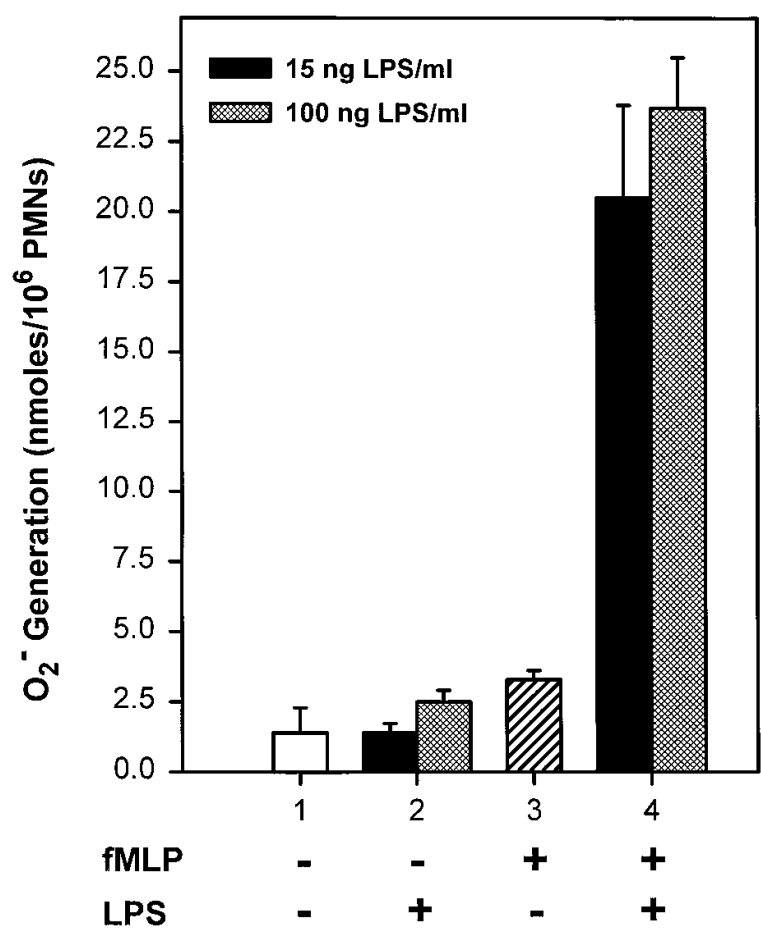

Figure 1. $\mathrm{O}_{2}^{-}$generation from PMNs after exposure to bacterial LPS. $5 \times 10^{5} \mathrm{PMNs}$ were incubated for $60 \mathrm{~min}$ at $37^{\circ} \mathrm{C}$ with or without LPS $(100 \mathrm{ng} / \mathrm{ml})$ and then with or without fMLP $(1 \mu \mathrm{M})$ for $10 \mathrm{~min}$ at $37^{\circ} \mathrm{C}$ as indicated. $\mathrm{O}_{2}{ }^{-}$generation was determined as described in Methods, and results are expressed as the mean \pm SD of four separate experiments.

ity (data not shown). The synergy between LPS and fMLP as agonist for $\mathrm{PMN} \mathrm{O}_{2}{ }^{-}$generation is consistent with previous reports $(30,32,34,48)$.

Enhanced $\mathrm{O}_{2}^{-}$production by plasma membrane-rich fractions of LPS-primed PMNs. Because the NADPH oxidase catalyzes the production of $\mathrm{O}_{2}^{-}$, we used a broken-cell NADPH oxidase reconstitution system to test the hypothesis that LPS directly affects NADPH oxidase components. PMNs treated with or without LPS were fractionated, and the $\mathrm{O}_{2}^{-}$generating activities of the plasma membrane- and specific granule-enriched fractions were compared. As shown in Fig. 2, incubation of cytosol and plasma membrane-rich fractions from LPS-treated PMNs produced approximately two times more $\mathrm{O}_{2}^{-}\left(1.2 \pm 0.24\right.$ nmole $\mathrm{O}_{2}^{-} / \mathrm{min} / 10^{7} \mathrm{CE}$; bar 3$)$ than analogous fractions from untreated cells $(0.63 \pm 0.28$; bar 1$)$ in the SDS-activated broken-cell assay. Similar results were obtained in a broken-cell system activated by PA and DiC8, agonists which might better represent signaling pathways triggered by fMLP $(39,49)$. Again, cytosol and plasma membrane-rich fractions from LPS-treated PMN elicited nearly twofold greater $\mathrm{O}_{2}{ }^{-}$-generating activity $\left(0.49 \pm 0.24\right.$ nmole $\mathrm{O}_{2}{ }^{-} / \mathrm{min} / 10^{7}$ $\mathrm{CE})$ compared with cytosol and plasma membrane-rich frac-

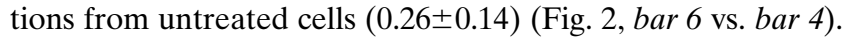
A similar enhancement of broken-cell $\mathrm{O}_{2}^{-}$-generating activity was observed when plasma membrane-rich fractions (from LPS-pretreated PMNs) were combined with cytosol obtained from either untreated or LPS-treated cells (compare bars 2 and 3 and bars 5 and 6 in Fig. 2). Thus, most of the enhanced 

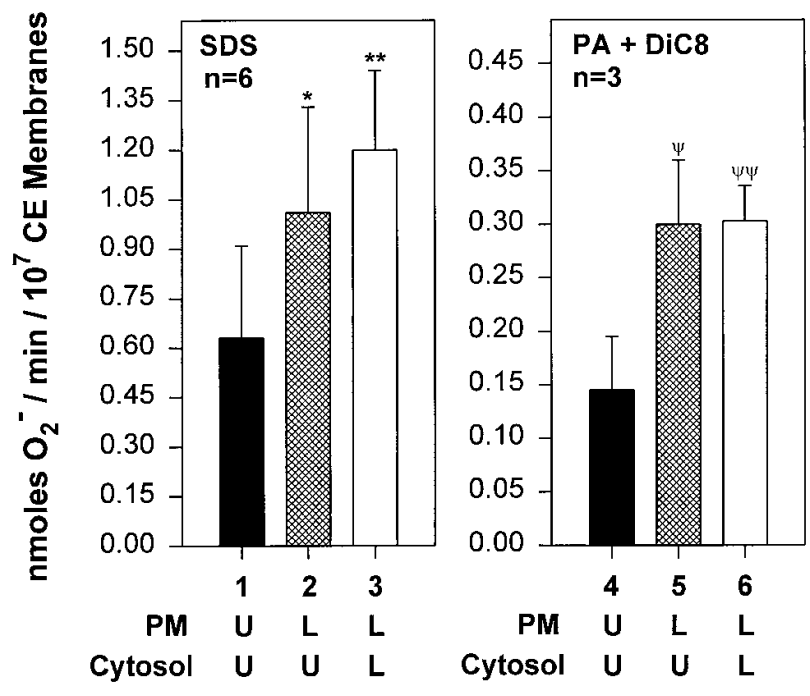

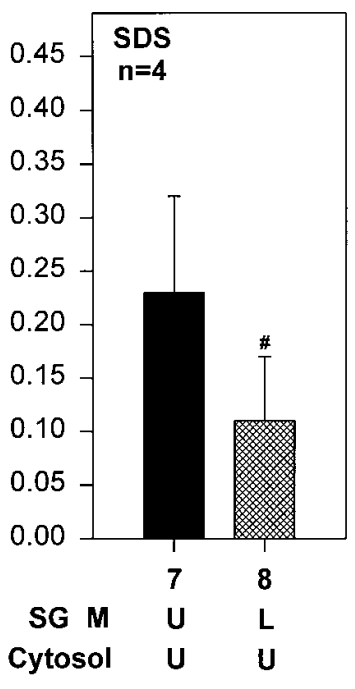

Figure 2. $\mathrm{O}_{2}{ }^{-}$-generating activity in plasma membrane- and specific granule-enriched fractions from LPS-treated PMNs. PMNs were treated with or without LPS ( $U$, untreated cells; $L$, LPS-treated cells) and then fractionated for use in broken-cell assays as described in Methods. Plasma membranerich fractions $(P M)$ and cytosol from untreated or LPS-treated PMNs were combined as indicated and then assayed for $\mathrm{O}_{2}{ }^{-}$-generating activity using SDS (bars 1-3) or PA + DiC8 (bars 4-6) as agonists. Specific granule-rich fractions $(S G M)$ from untreated (bar 7) or LPS-treated PMNs (bar 8) were combined with cytosol from untreated $\mathrm{PMNs}$, and $\mathrm{O}_{2}{ }^{-}$generation was determined as described in Methods. Results are expressed as the mean \pm SD of three to six separate experiments. The significance of $\mathrm{O}_{2}{ }^{-}$generation versus that of plasma membrane-enriched and cytosolic fractions from untreated PMNs was determined by paired Student's $t$ test: $* P=$ $0.0047, * * P=0.0042,{ }^{\psi} P=0.02,{ }^{*} P=$ $0.00062,{ }^{\#} P=0.01$. broken-cell $\mathrm{O}_{2}{ }^{-}$-generating activity reflected changes in the properties of the plasma membrane-rich fractions derived from LPS-treated PMNs.

LPS induces mobilization of flavocytochrome $b_{558}$ to the plasma membrane. It should be noted that whereas plasma membrane-rich fractions from LPS-treated cells showed increased NADPH oxidase activity when incubated with cytosol plus SDS or PA plus DiC8, these membrane fractions in the absence of added cytosol expressed very little activity $\left(0.25 \pm 0.03\right.$ nmole $\mathrm{O}_{2}^{-} / \mathrm{min} / 10^{7} \mathrm{CE}$ for assays without added cytosol vs. $1.2 \pm 0.24$ for assays containing added cytosol); $\mathrm{O}_{2}{ }^{-}$generating activity of plasma membrane-rich fractions (without added cytosol) from resting cells is $0.13 \pm 0.02$ nmole $\mathrm{O}_{2}^{-}$/ $\mathrm{min} / 10^{7} \mathrm{CE}$ ). These findings seem most compatible with a mobilization of flavocytochrome $b_{558}$-containing specific granules to the plasma membrane during PMN treatment with LPS rather than preassembly of the active $\mathrm{O}_{2}{ }^{-}$-generating complex. To test more directly the effect of LPS treatment on the subcellular localization of flavocytochrome $b_{558}$, we quantitated flavocytochrome $b_{558}$ in plasma membrane-rich fractions and in specific granules isolated from control and LPS-treated PMNs using oxidation-reduction difference spectroscopy. Spectral analysis revealed an increase in flavocytochrome $b_{558}$ in plasma membrane-rich fractions and a corresponding decrease in flavocytochrome $b_{558}$ from the specific granule-rich fractions after LPS treatment (Table I), consistent with an induction of specific granule exocytosis by LPS. The changes in flavocytochrome $b_{558}$ content of plasma membrane-rich fractions and specific granules paralleled changes in broken-cell NADPH oxidase activity expressed by these fractions in concert with cytosol. Thus, whereas the activity of plasma membrane-rich fractions (Fig. 2, bars 1-6) was increased by LPS treatment, the activity of the specific granules was decreased (Fig. 2, bars 7 and 8).

The data shown in Table I reproduce the subcellular distribution of flavocytochrome $b_{558}$ in control PMNs reported pre- viously $(23,24)$, and suggest that upregulation of plasma membrane-associated flavocytochrome $\mathrm{b}_{558}$ by LPS is the result of granule-plasma membrane fusion. However, one limitation of these data is that secretory vesicles copurify with plasma membrane vesicles using Percoll gradients (25), and, therefore, flavocytochrome $b_{558}$ recovered in plasma membrane-rich fractions of resting cells is derived from both plasma membrane and secretory vesicles. However, it is likely LPS elicits secretory vesicle mobilization before that of specific granules, in accordance with a reported hierarchy of granule exocytosis $(25,50)$.

To monitor more directly the mobilization of flavocytochrome $b_{558}$ to the plasma membrane during LPS treatment, PMNs were analyzed by flow cytometry using an mAb (7D5) which recognizes an extracytoplasmic epitope of flavocytochrome $b_{558}$. FACScan analysis indicated 7D5 bound PMNs from healthy individuals, but did not bind to PMNs from a patient with X-linked CGD, indicating the specificity of 7D5 for

Table I. Subcellular Distribution of Flavocytochrome $b_{558}$ after LPS Exposure

\begin{tabular}{lcccc}
\hline \multicolumn{1}{c}{ PMN treatment } & \multicolumn{2}{c}{ Plasma membrane } & \multicolumn{2}{c}{ Specific granule membrane } \\
\hline & conc. $($ pmol $)$ & $\%$ total & conc. (pmol) & $\%$ total \\
Untreated PMNs & $4.33 \pm 0.85$ & $(25.9 \%)$ & $12.36 \pm 5.7$ & $(74.1 \%)$ \\
LPS-treated PMNs & $6.42 \pm 0.66$ & $(40.6 \%) *$ & $9.34 \pm 4.6$ & $(59.1 \%)^{\ddagger}$
\end{tabular}

PMNs incubated with or without LPS were fractionated, and flavocytochrome $b_{558}$ in plasma membrane- and specific granule-enriched fractions was quantitated by oxidation-reduction spectroscopy. Flavocytochrome $b_{558}$ concentration (from $10^{7} \mathrm{CE}$ ) is expressed as the mean $\pm \mathrm{SD}$ of four separate experiments. Statistical analyses were performed using the paired Student's $t$ test. $* P=0.007$ vs. untreated plasma membranes. ${ }^{\ddagger} P<0.05$ vs. untreated specific granule membranes. 

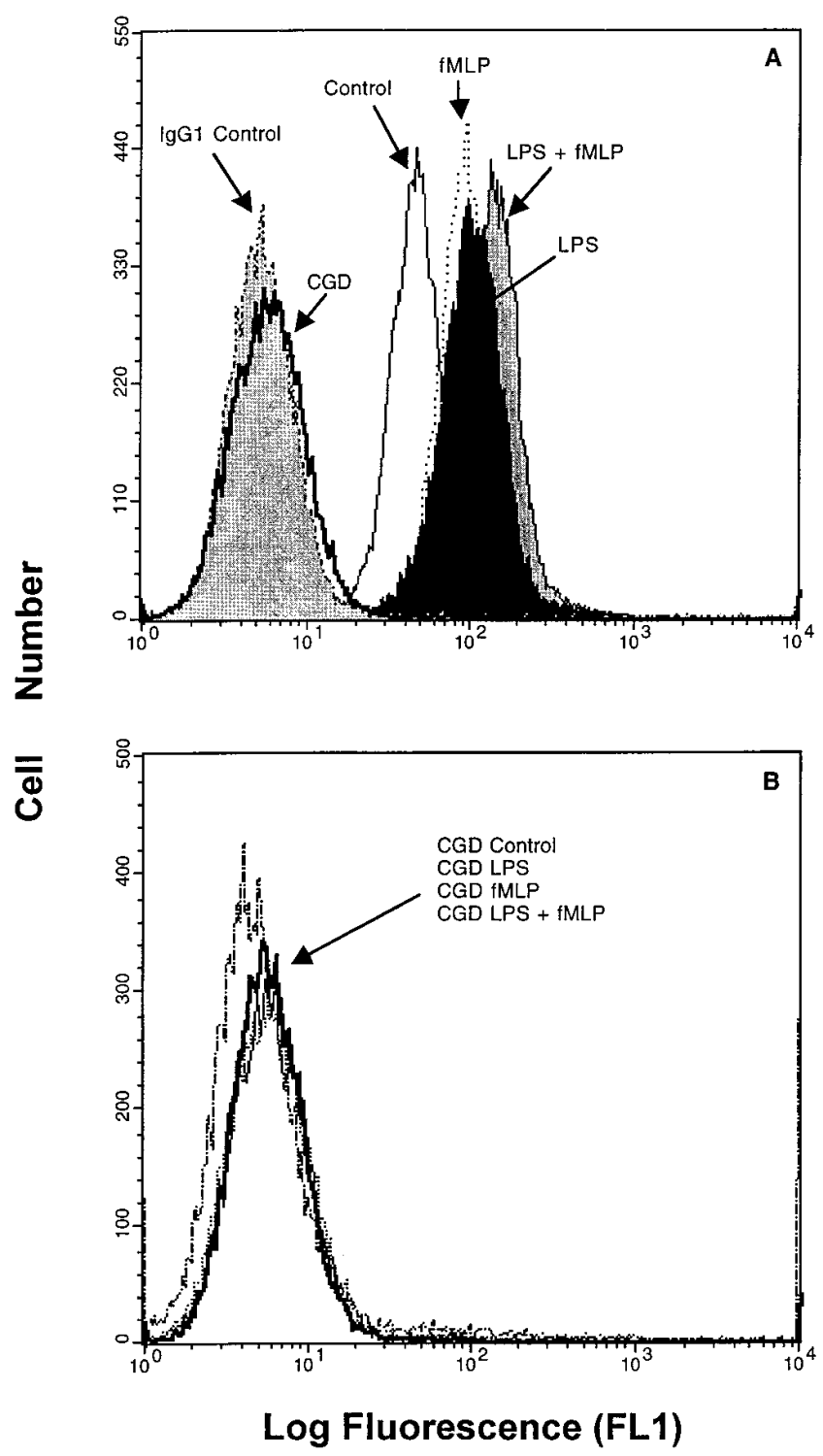

Figure 3. Plasma membrane association of flavocytochrome $b_{558}$ after LPS treatment. PMNs from healthy subjects $(A)$ or from an individual with X-linked CGD $(B)$ were treated with or without LPS (60 min at $37^{\circ} \mathrm{C}$ with $100 \mathrm{ng} \mathrm{LPS} / \mathrm{ml}$ ) and subsequently with or without fMLP $(1 \mu \mathrm{M})$ for an additional $10 \mathrm{~min}$ and then probed with 7D5, an mAb which recognizes an extracytoplasmic epitope of flavocytochrome $\mathrm{b}_{558}$. PMNs stained with a control IgG1 mAb of the same isotype as 7D5 and untreated PMNs from an individual with CGD were included for comparison $(A)$. Results are from one experiment representative of five ( $A$, healthy cells) or two ( $B$, CGD cells).

flavocytochrome $\mathrm{b}_{558}$ (Fig. $3 A$ ). Furthermore, PMNs treated with or without LPS $\left(100 \mathrm{ng} / \mathrm{ml}\right.$ for up to $90 \mathrm{~min}$ at $\left.37^{\circ} \mathrm{C}\right)$ and subsequently with or without fMLP $\left(1 \mu \mathrm{M}\right.$ for $10 \mathrm{~min}$ at $\left.37^{\circ} \mathrm{C}\right)$ revealed a hierarchy of stimuli for increasing plasma membrane association of flavocytochrome $b_{558}$ : LPS + fMLP > fMLP $\geq$ LPS $>$ control PMNs. In contrast, PMNs from a patient with $\mathrm{X}$-linked CGD did not show increased plasma membrane-associated flavocytochrome $b_{558}$ in response to LPS, fMLP, or to a sequential treatment of LPS and fMLP (Fig. 3 $B)$. Although addition of fMLP to LPS-pretreated PMNs fur- ther augmented the translocation of flavocytochrome $b_{558}$ to the plasma membrane, the increase in cell surface flavocytochrome $b_{558}$ at the time of maximal activation of the NADPH oxidase activity by fMLP ( $<2 \min [51])$ was very limited (Fig. 4). Thus, it is unlikely that this effect was entirely responsible for the dramatic increase in NADPH oxidase activity observed promptly after fMLP addition to LPS-primed cells. In contrast, the time-dependent mobilization of flavocytochrome $b_{558}$ to the plasma membrane induced by LPS closely paralleled LPS priming (references 30,32, 34, and 52, and data not shown), suggesting that LPS-induced translocation of flavocytochrome $\mathrm{b}_{558}$ may underlie LPS priming of the fMLP-triggered respiratory burst.

Translocation of p47/67-phox and Rac2 from cytosol to the plasma membrane occurs mainly after addition of fMLP to LPS-primed PMNs. The absence of significant NADPH oxidase activity either in intact cells or plasma membrane-enriched, cytosol-free fractions after LPS treatment despite the mobilization of flavocytochrome $b_{558}$ suggests that essential cytosolderived cofactors of the oxidase may not be mobilized during LPS treatment. To test this hypothesis, plasma membraneenriched fractions from PMNs treated with or without LPS and subsequently with or without fMLP were isolated and probed for associated p47-phox, p67-phox, and Rac2. Plasma membrane-rich fractions from PMNs treated with LPS alone showed a small (approximately threefold) increase in p47phox but little increase in either p67-phox or Rac2 (Fig. 5, $A$ and $B$ ). Time-course analysis of LPS-induced mobilization of p47-phox to the plasma membrane-enriched fraction indicated

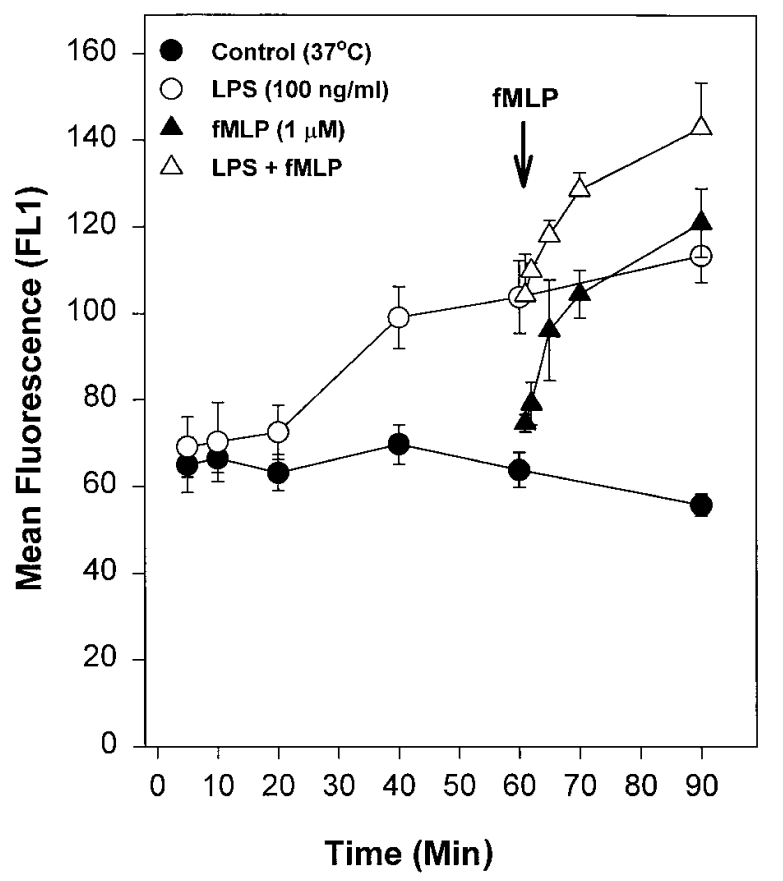

Figure 4. Time-dependent mobilization of flavocytochrome $b_{558}$ to the plasma membrane after LPS treatment. PMNs from healthy subjects were treated with $(O, \triangle)$ or without $(\bullet, \mathbf{\Delta}) 100 \mathrm{ng} \mathrm{LPS} / \mathrm{ml}$ for the indicated times at $37^{\circ} \mathrm{C}$ and probed with $7 \mathrm{D} 5$, or were stimulated subsequently with fMLP $(1 \mu \mathrm{M})(\triangle, \boldsymbol{\Delta})$ for the additional indicated times and then probed with 7D5. Results are expressed as the mean fluorescence $\pm \mathrm{SD}$ of three to five separate experiments. 


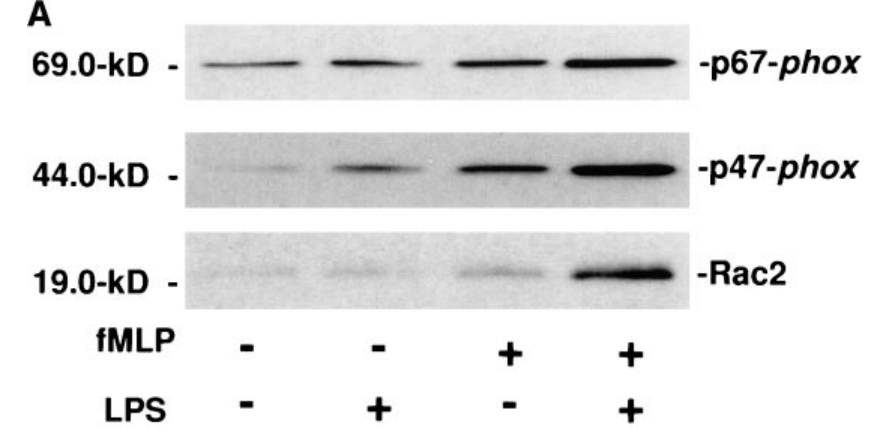

-p67-phox
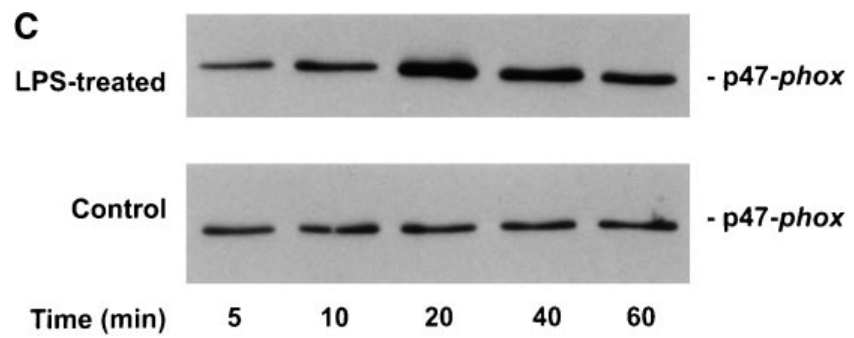

B

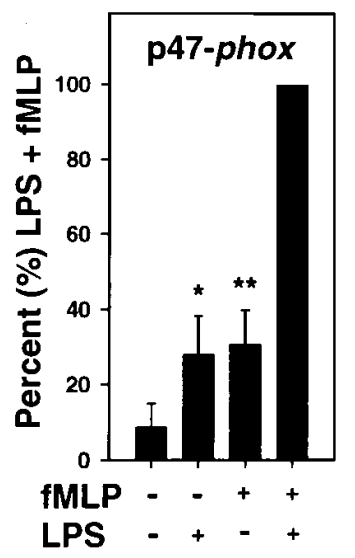

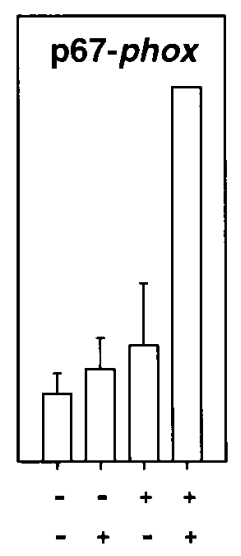
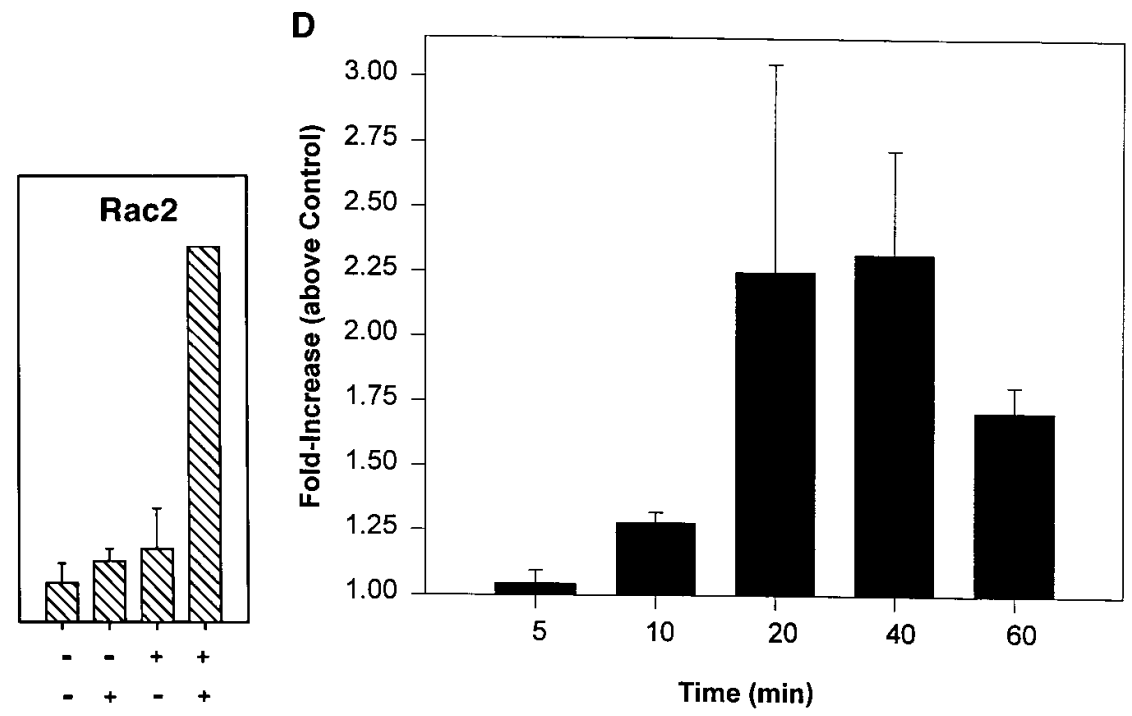

Figure 5. Analysis of plasma membrane-associated p47/67-phox and Rac2 in PMNs after exposure to bacterial LPS. Plasma membrane-rich fractions isolated from PMNs treated with or without LPS (60 min at $37^{\circ} \mathrm{C}$ with $\left.100 \mathrm{ng} \mathrm{LPS} / \mathrm{ml}\right)$ and subsequently with or without fMLP $(10 \mathrm{~min}$ at $37^{\circ} \mathrm{C}$ with $1 \mu \mathrm{M}$ fMLP) as indicated were probed for associated p47-phox, p67-phox, and Rac2 $(A)$ and then quantitated by densitometry $(B)$. Alternatively, plasma membrane-rich fractions isolated from PMNs treated with or without $100 \mathrm{ng}$ LPS/ml for the indicated times were probed for associated p47-phox $(C)$ and then quantitated by densitometry $(D)$. Results in $A$ are from one experiment representative of three. Translocation is expressed as a percentage of the fully activated assay (LPS-treated followed by fMLP-stimulated; \% $L P S+f M L P$ ), and is the mean \pm SD of at least three separate experiments $(B)$. Results in $C$ are from one experiment representative of two. These results are also represented densitometrically in $D$, and are expressed as the mean $\pm \mathrm{SD}$ of two separate experiments.

that translocation had similar kinetics as the LPS-induced upregulation of flavocytochrome $b$ and that of LPS priming in general $(30,33,34)$, providing additional evidence that LPS priming for an augmented respiratory burst is the direct result of redistribution of NADPH oxidase components (Fig. 5, C and $D$ ). Analogous fractions from PMNs treated with fMLP alone showed a similarly small increase in all three cytosolic oxidase components (Fig. 5, $A$ and $B$ ). However, when fMLP was added to LPS-pretreated PMNs, translocation of all three cytosolic protein species was enhanced dramatically; the levels of p47-phox, p67-phox, and Rac2 in the plasma membraneenriched fractions were $\sim 10$-fold above normal resting levels (Fig. 5, $A$ and $B$ ). The combined effect of LPS and fMLP on the translocation of p47-phox, p67-phox, and Rac2 is much greater than additive, and correlates well with the relative levels of $\mathrm{O}_{2}{ }^{-}$-generating activity expressed by intact PMNs under these different conditions.

Phosphorylation of p47-phox induced by LPS and/or $f M L P$. Previous studies have shown that phosphorylation and translocation of p47-phox correlate with activation of the res- piratory burst in PMNs $(46,53,54)$. To investigate further the possible role of p47-phox phosphorylation in LPS priming, we analyzed the effects of LPS pretreatment on the phosphorylation of p47-phox in fMLP-stimulated PMNs. LPS pretreatment of PMNs caused a detectable, albeit slight increase in the phosphorylation of p47-phox versus control cells (Fig. $6 \mathrm{~A}$ ). Phosphorylation of p47-phox was increased roughly fivefold when PMNs were treated with fMLP alone but was enhanced only slightly further in cells pretreated with LPS before addition of fMLP (Fig. $6 A$ ). Thus, whereas translocation of p47-phox correlated with augmented $\mathrm{O}_{2}{ }^{-}$-generating activity in cells treated sequentially with LPS and fMLP (compare Figs. 1 and 5), phosphorylation of p47-phox after fMLP stimulation did not appear similarly enhanced by LPS pretreatment (compare Figs. 1 and 5 with Fig. 6). Because the results shown in Fig. $6 \mathrm{~A}$ include combined membrane and cytosolic pools of p47-phox, it could be argued that differences in the plasma membranebound phosphorylated p47-phox might be masked by additional phosphorylated cytosolic species. Plasma membranerich fractions from PMNs pretreated with LPS and then 


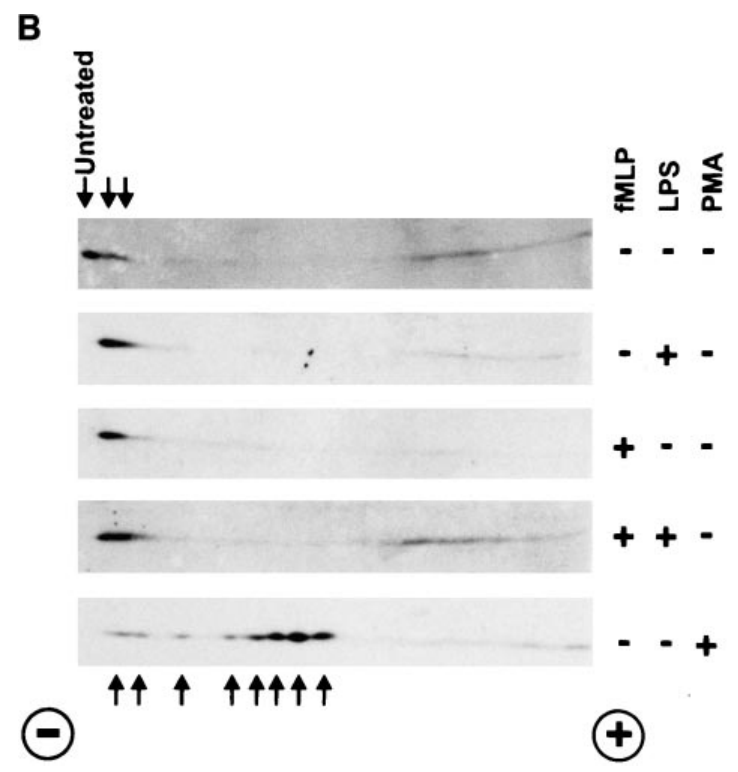

Figure 6. Effect of LPS treatment on the phosphorylation of p47-phox. PMNs loaded with

$\left[{ }^{32} \mathrm{P}\right]$ orthophosphate were treated with or without LPS $\left(60 \mathrm{~min}\right.$ at $37^{\circ} \mathrm{C}$ with $100 \mathrm{ng}$ LPS $/ \mathrm{ml}$ ) and subsequently with or without fMLP $(1 \mu \mathrm{M}$ fMLP for $10 \mathrm{~min}$ at $37^{\circ} \mathrm{C}$ ) as indicated, and $\mathrm{p} 47$ -

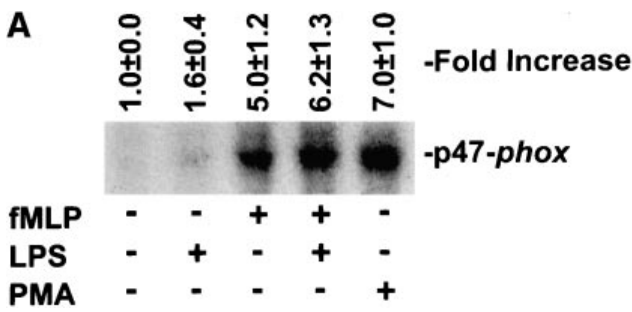

phox was immunoprecipitated as described in Methods $(A)$. The immunoprecipitate from PMNs stimulated with 2 $\mu \mathrm{g} / \mathrm{ml}$ PMA was included for comparison $(A)$. Alternatively, plasma membrane-enriched fractions from PMNs treated with or without LPS (60 $\mathrm{min}$ at $37^{\circ} \mathrm{C}$ with $\left.100 \mathrm{ng} \mathrm{LPS} / \mathrm{ml}\right)$ and subsequently with or without fMLP $\left(1 \mu \mathrm{M}\right.$ fMLP for $10 \mathrm{~min}$ at $\left.37^{\circ} \mathrm{C}\right)$ as indicated were analyzed by two-dimensional gel electrophoresis as described in Methods $(B)$. $B$ is an immunoblot probed with p47-phox antibody. Since there was less immunoreactive p47-phox in plasma membrane-rich fractions of untreated PMNs (top), it was necessary to expose that immunoblot longer to x-ray film in order to visualize a signal which would serve as a comparative standard for immunoblots of analogous fractions after specified treatments. Arrows, Relative position of various p47-phox species; electrode charge during NEPHGE is indicated (bottom). Results are from one experiment representative of two, and quantitation is expressed as fold-increase relative to phosphorylation in untreated PMN immunoprecipitates (1.0), and is the mean $\pm \mathrm{SD}$ of two separate experiments.

treated with fMLP do not show a substantially greater accumulation of more acidic (i.e., phosphorylated) p47-phox species than do cells at rest or after treatment with LPS or fMLP alone (Fig. $6 \mathrm{~B}$ ). The limited effects of LPS and/or fMLP on phosphorylation of p47-phox are particularly striking when juxtaposed with the effects of PMA, both quantitatively and qualitatively. Incorporation of ${ }^{32} \mathrm{P}$ into $\mathrm{p} 47-p h o x$ was nearly sevenfold greater after PMA treatment than after LPS alone (Fig. $6 \mathrm{~A}$ ), whereas incorporation of ${ }^{32} \mathrm{P}$ into $\mathrm{p} 47$-phox after a sequential treatment of LPS and fMLP was similar in magnitude to that of PMA (Fig. $6 \mathrm{~A}$ ). By contrast, plasma membrane-rich fractions from PMNs treated with PMA contained at least eight acidic derivatives of p47-phox, including several species more acidic than the most anodal species accumulating after treatment with LPS and/or fMLP. Analogous fractions obtained from PMNs treated with LPS, fMLP, or LPS and fMLP sequentially contained only one or two more acidic species of p47-phox than did untreated PMNs (Fig. 6 B). These findings suggest that even limited phosphorylation of p47-phox induced by LPS and/or fMLP may play an important role in p47-phox translocation and respiratory burst activation (46, 53-55). Since there are few anodal plasma membrane-associated species of p47-phox in any of the LPS/fMLP combinations (Fig. $6 \mathrm{~B}$ ), the effects of LPS and fMLP may only transiently involve phosphorylation of p47-phox or be limited to one or two important phosphorylation sites affecting a small percentage of total p47-phox. However, we cannot exclude the possible existence of an alternative phosphorylation-independent pathway of NADPH oxidase activation as suggested previously by Robinson et al. (56), or a possible lack of correlation between phosphorylation and translocation with certain ago- nists as reported previously (51). Studies are currently under way to determine the location and kinetics of these limited LPS- and/or fMLP-induced phosphorylation events.

In summary, our data suggest that LPS priming for enhanced $\mathrm{O}_{2}^{-}$generation by fMLP-stimulated PMNs reflects redistribution of NADPH oxidase components, thereby facilitating increased assembly of the NADPH oxidase. The effects of LPS and fMLP on this assembly process appear to be distinct: LPS pretreatment induces mainly translocation of flavocytochrome $b_{558}$ from specific granules to the plasma membrane, with limited translocation of p47-phox but little concomitant translocation of p67-phox or Rac2 from the cytosol. In contrast, subsequent treatment with fMLP rapidly induces translocation of all three cytosolic components to the plasma membrane, with little additional recruitment of flavocytochrome $\mathrm{b}_{558}$. Previous attempts $(30,32)$ antedated the more detailed characterization of cytosolic components and precise definition of the subcellular distribution of the flavocytochrome $b$ available today. Specifically, the method used by Forehand et al. to isolate plasma membrane vesicles also coisolated specific granules (32). Therefore, LPS-augmented, plasma membraneassociated $\mathrm{O}_{2}^{-}$-generating activity resulting from flavocytochrome $\mathrm{b}$ redistribution would have gone unnoticed as reported (32).

The events reported here appear to be directly responsible for the enhanced respiratory burst observed in LPS-primed PMNs, since translocation of cytosolic oxidase components is closely associated with $\mathrm{O}_{2}{ }^{-}$generation $(8,9)$. However, it is apparent that other more proximal events result in upregulation of the NADPH oxidase after LPS exposure and involve a variety of signaling pathways $(28,32,33,52)$. Recently, El Benna 
and co-workers proposed that p47-phox could be phosphorylated by p38 mitogen-activated protein kinase (57), a kinase reported by Nick et al. to be activated by LPS (28). Thus, the importance of LPS-induced phosphorylation pathways on NADPH oxidase activation remains to be determined.

In view of the acute but short-lived activation of the respiratory burst that is triggered by $\operatorname{fMLP}(30,49)$, we propose that LPS priming of this process represents cellular and/or biochemical alterations that increase the efficiency of NADPH oxidase assembly and subsequent generation of $\mathrm{O}_{2}{ }^{-}$. The increased efficiency with which $\mathrm{O}_{2}{ }^{-}$can be generated translates to more efficient microbial killing and an overall better host response to invading microorganisms. Characterization of the molecular and cellular basis for LPS-dependent mobilization of flavocytochrome $b_{558}$ and modulation of specific signaling events involved in translocation of p47-phox, p67-phox, and Rac2 awaits further study.

\section{Acknowledgments}

We thank Drs. David J. Kusner, Shankar S. Iyer, Lee-Ann Allen, Gerene Denning, Bradley E. Britigan, and Rich Fawcett for invaluable input throughout these studies, and Ward M. Jones (Montana State University) for advice on flow cytometry.

This work was supported in part by U.S. Public Health Service post-doctoral training grant 5-T32-AI07343-09 (to F.R. DeLeo) and U.S. Public Health Service research grants AI-HL35879 (to W.M. Nauseef), DK05472 (to J.P. Weiss), and AI-24616 and AI-8384 (to M. Apicella), a Veterans Administration Merit Review (to W.M. Nauseef), and a Howard Hughes Investigator Award (to W.M. Nauseef and M. Apicella).

\section{References}

1. Boxer, G.J., J.T. Curnutte, and L.A. Boxer. 1985. Polymorphonuclear leukocyte function. Hosp. Pract. 40:69-90.

2. DeLeo, F.R., and M.T. Quinn. 1996. Assembly of the phagocyte NADPH oxidase: molecular interaction of oxidase proteins. J. Leukocyte Biol. 60:677691.

3. Robinson, J.M., and J.A. Badwey. 1995. The NADPH oxidase complex of phagocytic leukocytes: a biochemical and cytochemical view. Histochemistry. 103:163-180.

4. Jesaitis, A.J., M.T. Quinn, G. Mukherjee, P.A. Ward, and E.A. Dratz. 1991. Death by oxygen: radical views. The molecular basis of oxidative damage by leukocytes: a Montana State University/Keystone Symposium, Big Sky, MT, USA, January 28-February 3, 1991. New Biol. 3:651-655.

5. Berendes, H., R.A. Bridges, and R.A. Good. 1957. A fatal granulomatosus of childhood-the study of a new syndrome. Minn. Med. 309-312.

6. Thrasher, A.J., N.H. Keep, F. Wientjes, and A.W. Segal. 1994. Chronic granulomatous disease. Biochim. Biophys. Acta. 1227:1-24.

7. Royer-Pokora, B., L.M. Kunkel, A.P. Monaco, S.C. Goff, P.E. Newburger, R.L. Baehner, F.S. Cole, J.T. Curnutte, and S.H. Orkin. 1986. Cloning the gene for an inherited human disorder-chronic granulomatous disease-on the basis of its chromosomal location. Nature. 322:32-38.

8. Clark, R.A., B.D. Volpp, K.G. Leidal, and W.M. Nauseef. 1990. Two cytosolic components of the human neutrophil respiratory burst oxidase translocate to the plasma membrane during cell activation. J. Clin. Invest. 85:714-721.

9. Quinn, M.T., T. Evans, L.R. Loetterle, A.J. Jesaitis, and G.M. Bokoch. 1993. Translocation of Rac correlates with NADPH oxidase activation: evidence for equimolar translocation of oxidase components. J. Biol. Chem. 268: 20983-20987.

10. Volpp, B.D., W.M. Nauseef, and R.A. Clark. 1988. Two cytosolic neutrophil oxidase components absent in autosomal chronic granulomatous disease. Science. 242:1295-1297.

11. Nunoi, H., D. Rotrosen, J.I. Gallin, and H.L. Malech. 1988. Two forms of autosomal chronic granulomatous disease lack distinct neutrophil cytosolic factors. Science. 242:1298-1301.

12. Volpp, B.D., W.M. Nauseef, J.E. Donelson, D.R. Moser, and R.A. Clark. 1989. Cloning of the cDNA and functional expression of the 47-kilodalton cytosolic component of human neutrophil respiratory burst oxidase. Proc. Natl. Acad. Sci. USA. 86:7195-7199.

13. Lomax, K.J., T.L. Leto, H. Nunoi, J.I. Gallin, and H.L. Malech. 1989.
Recombinant 47-kilodalton cytosolic factor restores NADPH oxidase in chronic granulomatous disease. Science. 245:409-412.

14. Leto, T.L., K.J. Lomax, B.D. Volpp, H. Nunoi, J.M.G. Sechler, W.M Nauseef, R.A. Clark, J.I. Gallin, and H.L. Malech. 1990. Cloning of a 67-kD neutrophil oxidase factor with similarity to a noncatalytic region of p60-src. Science. 248:727-730.

15. Knaus, U.G., P.G. Heyworth, T. Evans, J.T. Curnutte, and G.M. Bokoch. 1991. Regulation of phagocyte oxygen radical production by the GTPbinding protein Rac2. Science. 254:1512-1515.

16. Abo, A., and E. Pick. 1991. Purification and characterization of a third cytosolic component of the superoxide-generating NADPH oxidase of macrophages. J. Biol. Chem. 266:23577-23585.

17. Parkos, C.A., M.C. Dinauer, L.E. Walker, R.A. Allen, A.J. Jesaitis, and S.H. Orkin. 1988. Primary structure and unique expression of the 22-kilodalton light chain of human neutrophil cytochrome b. Proc. Natl. Acad. Sci. USA. 85: 3319-3323.

18. Parkos, C.A., R.A. Allen, C.G. Cochrane, and A.J. Jesaitis. 1987. Purified cytochrome $\mathrm{b}$ from human granulocyte plasma membrane is composed of two polypeptides with relative molecular weights of 91,000 and 22,000. J. Clin. Invest. 80:732-742.

19. Quinn, M.T., C.A. Parkos, L. Walker, S.H. Orkin, M.C. Dinauer, and A.J. Jesaitis. 1989. Association of a ras-related protein with cytochrome b of human neutrophils. Nature. 342:198-200.

20. Wientjes, F.B., J.J. Hsuan, N.F. Totty, and A.W. Segal. 1993. p40 phox , a third cytosolic component of the activation complex of the NADPH oxidase to contain src homology 3 domains. Biochem. J. 296:557-561.

21. Jesaitis, A.J. 1995. Structure of human phagocyte cytochrome $b$ and its relationship to microbicidal superoxide production. J. Immunol. 155:3286-3288

22. Koshkin, V., and E. Pick. 1993. Generation of superoxide by purified and relipidated cytochrome $b_{559}$ in the absence of cytosolic activators. FEBS (Fed. Eur. Biochem. Soc.) Lett. 327:57-62.

23. Borregaard, N., J.M. Heiple, E.R. Simons, and R.A. Clark. 1983. Subcellular localization of the b-cytochrome component of the human neutrophil microbicidal oxidase: translocation during activation. J. Cell. Biol. 97:52-61.

24. Ohno, Y., B.E. Seligmann, and J.I. Gallin. 1985. Cytochrome $b$ translocation to human neutrophil plasma membranes and superoxide release. Differential effects of $N$-formymethionylleucylphenylalanine, phorbol myristate acetate, and A23187. J. Biol. Chem. 201:2409-2414.

25. Borregaard, N., K. Lollike, L. Kjeldsen, H. Sengelov, L. Bastholm, M.H Nielsen, and D.F. Bainton. 1993. Human neutrophil granules and secretory vesicles. Eur. J. Haematol. 51:187-198.

26. Vosbeck, K., P. Tobias, H. Mueller, R.A. Allen, K.E. Arfors, R.J. Ulevitch, and L.A. Sklar. 1990. Priming of polymorphonuclear granulocytes by lipopolysaccharides and its complexes with lipopolysaccharide binding protein and high density lipoprotein. J. Leukocyte Biol. 47:97-104.

27. Lundqvist, H., A. Karlsson, P. Follin, C. Sjölin, and C. Dahlgren. 1992. Phagocytosis following translocation of the neutrophil b-cytochrome from the specific granule to the plasma membrane is associated with an increased leakage of reactive oxygen species. Scand. J. Immunol. 36:885-891.

28. Nick, J.A., N.J. Avidi, P. Gerwins, G.L. Johnson, and G.S. Worthen. 1996. Activation of a p38 mitogen-activated protein kinase in human neutrophils by lipopolysaccharide. J. Immunol. 156:4867-4875.

29. Condliffe, A.M., E.R. Chilvers, C. Haslett, and I. Dransfield. 1996. Priming differentially regulates neutrophil adhesion molecule expression/function. Immunology. 89:105-111.

30. Guthrie, L.A., L.C. McPhail, P.M. Henson, and R.B. Johnston, Jr. 1984 Priming of neutrophils for enhanced release of oxygen metabolites by bacterial lipopolysaccharide. Evidence for increased activity of the superoxide-producing enzyme. J. Exp. Med. 160:1656-1671.

31. Haslett, C., L.A. Guthrie, M.M. Kopaniak, R.B. Johnston, and P.M. Henson. 1985. Modulation of multiple neutrophil functions by preparative methods or trace concentrations of bacterial lipopolysaccharide. Am. J. Pathol. 119:101-110.

32. Forehand, J.R., M.J. Pabst, W.A. Phillips, and R.B. Johnston, Jr. 1989. Lipopolysaccharide priming of human neutrophils for an enhanced respiratory burst. Role of intracellular free calcium. J. Clin. Invest. 83:74-83.

33. Worthen, G.S., J.F. Seccombe, K.L. Clay, L.A. Guthrie, and R.B. Johnston. 1988. The priming of neutrophils by lipopolysaccharide for production of intracellular platelet-activating factor. Potential role in mediation of enhanced superoxide secretion. J. Immunol. 3553-3559.

34. Aida, Y., and M.J. Pabst. 1990. Priming of neutrophils by lipopolysaccharide for enhanced release of superoxide. Requirement for plasma but not for tumor necrosis factor alpha. J. Immunol. 145:3017-3025.

35. Johnson, K.G., and M.B. Perry. 1976. Improved techniques for the preparation of bacterial lipopolysaccharides. Can. J. Microbiol. 22:29-34.

36. Boyum, A. 1968. Isolation of mononuclear cells and granulocytes from human blood. J. Clin. Lab. Invest. 21:77-89.

37. Clark, R.A., K.G. Leidel, D.W. Pearson, and W.M. Nauseef. 1987. NADPH oxidase of human neutrophils. Subcellular localization and characterization of an arachidonate-activatable superoxide-generating system. J. Biol. Chem. 262:4065-4074.

38. DeLeo, F.R., K.V. Ulman, A.R. Davis, K.L. Jutila, and M.T. Quinn. 
1996. Assembly of the human neutrophil NADPH oxidase involves binding of p67phox and flavocytochrome b to a common functional domain in p47phox. $J$. Biol. Chem. 271:17013-17020.

39. Qualliotine-Mann, D., D.E. Agwu, M.D. Ellenburg, C.E. McCall, and L.C. McPhail. 1993. Phosphatidic acid and diacylglycerol synergize in a cell-free system for activation of NADPH oxidase from human neutrophils. J. Biol. Chem. 268:23843-23849.

40. Metcalf, J.A., J.I. Gallin, W.M. Nauseef, and R.K. Root. 1983. Laboratory Manual of Neutrophil Function. Raven Press, Ltd., New York. 191 pp.

41. Mizuno, Y., T. Hara, M. Nakamura, K. Ueda, S. Minakami, and H. Take. 1988. Classification of chronic granulomatous disease on the basis of monoclonal antibody-defined surface cytochrome b deficiency. J. Pediatr. 113: $458-462$

42. Nakamura, M., M. Murakami, T. Koga, Y. Tanaka, and S. Minakami. 1987. Monoclonal antibody 7D5 raised to cytochrome $b_{558}$ of human neutrophils: immunocytochemical detection of the antigen in peripheral phagocytes of normal subjects, patients with chronic granulomatous disease, and their carrier mothers. Blood. 69:1404-1408.

43. Jones, W.M., B.A. Walcheck, and M.A. Jutila. 1996. Generation of a new gamma delta T cell-specific monoclonal antibody (GD 3.5). Biochemical comparisons of GD 3.5 antigen with the previously described Workshop Cluster 1 (WC1) family. J. Immunol. 156:3772-3779.

44. Gallagher, S.R., J.A. Smith, S.E. Winston, S.A. Fuller, and J.G.R. Hurrell. 1993. Current Protocols in Molecular Biology. Greene Publishing Associates Inc., and John Wiley \& Sons, Inc., New York.

45. Nauseef, W.M., S.J. McCormick, and R.A. Clark. 1995. Calreticulin functions as a molecular chaperone in the biosynthesis of myeloperoxidase. $J$. Biol. Chem. 270:4741-4747.

46. Nauseef, W.M., B.D. Volpp, and R.A. Clark. 1990. Immunochemical and electrophoretic analyses of phosphorylated native and recombinant neutrophil oxidase component p47-phox. Blood. 76:2622-2629.

47. Schumann, R.R., J.R. Leong, G.W. Flaggs, P.W. Gray, S.D. Wright, J.C. Madison, P.S. Tobias, and R.J. Ulevitch. Structure and function of lipopolysaccharide binding protein. 1990. Science. 249:1429-1431.
48. Shapira, L., C. Champagne, B. Gordon, S. Amar, and T.E. Van Dyke. 1995. Lipopolysaccharide priming of superoxide release by human neutrophils: role of membrane CD14 and serum LPS binding protein. Inflammation. 19:289295

49. McPhail, L.C., D. Qualliotine-Mann, and K.A. Waite. 1995. Cell-free activation of neutrophil NADPH oxidase by a phosphatidic acid-regulated protein kinase. Proc. Natl. Acad. Sci. USA. 92:7931-7935.

50. Sengelov, H., P. Follin, L. Kjeldsen, K. Lollike, C. Dahlgren, and N. Borregaard. 1995. Mobilization of granules and secretory vesicles during in vivo exudation of human neutrophils. J. Immunol. 154:4157-4165.

51. Dusi, S., V. Della Bianca, M. Grzeskowiak, and F. Rossi. 1993. Relationship between phosphorylation and translocation to the plasma membrane of p47-phox and p67-phox and activation of the NADPH oxidase in normal and $\mathrm{Ca}^{2+}$-depleted human neutrophils. Biochem. J. 290:173-178.

52. Doefler, M.E., J. Weiss, J.D. Clark, and P. Elsbach. 1994. Bacterial lipopolysaccharide primes human neutrophils for enhanced release of arachidonic acid and causes phosphorylation of an $85-\mathrm{kD}$ cytosolic phospholipase $\mathrm{A}_{2}$. J. Clin. Invest. 93:1583-1591.

53. Heyworth, P.G., and J.A. Badwey. 1990. Continuous phosphorylation of both the 47 and the $49 \mathrm{kDa}$ proteins during superoxide production by neutrophils. Biochim. Biophys. Acta. 1052:299-305.

54. Rotrosen, D., and T.L. Leto. 1990. Phosphorylation of neutrophil 47-kDa cytosolic oxidase factor. Translocation to membrane is associated with distinct phosphorylation events. J. Biol. Chem. 265:19910-19915.

55. Hayakawa, T., K. Suzuki, S. Suzuki, P.C. Andrews, and B.M. Babior. 1986. A possible role for protein phosphorylation in the activation of the respiratory burst in human neutrophils. J. Biol. Chem. 261:9109-9115.

56. Robinson, J.M., P.G. Heyworth, and J.A. Badwey. 1990. Utility of staurosporine in uncovering differences in the signal transduction pathways for superoxide production in neutrophils. Biochim. Biophys. Acta. 1055:55-62.

57. El Benna, J., J. Han, J.-W. Park, E. Schmid, R.J. Ulevitch, and B.M. Babior. 1996. Activation of p38 in stimulated human neutrophils: phosphorylation of the oxidase component p47phox by p38 and ERK but not by JNK. Arch. Biochem. Biophys. 334:395-400. 